\title{
Dementia, delirium \& neuropsychiatric conditions in Charaka indriya sthana
}

\begin{abstract}
Charaka Samhita is the oldest and most authentic treatise on Ayurveda (an ancient Indian system of medicine). Indriya sthana (prognostic medicine) is one among the eight sections of Charaka samhita and it deals with prognostic aspects. Arishta lakshanas are the signs and symptoms which indicates imminent death. Various psychiatric and neuropsychiatric conditions are mentioned throughout 'Charaka Indriya sthana' in a scattered form. Dementia and delirium are commonly seen at terminal stages or at the end-of-life. As indriya sthana deals with terminal illnesses or end-of-life stages, there is a hypothesis that description of conditions like dementia and delirium may be traceable in 'Charaka indriya sthana'. The present study attempts to screen various references pertaining to psychiatric and neuropsychiatric conditions of 'Charaka Indriya sthana' and explore their rationality, clinical and prognostic significance in present era. Dementia, Delirium and neuropsychiatric conditions of 'Charaka Indriya sthana' have been explored in the present study. 'Dementia' and 'Delirium' are the two most common conditions found through out 'Charaka indriya sthana'. Various references related to other psychiatric and neuropsychiatric conditions like, 'Hallucinations', 'Trichotillomania', 'Bruxism', 'Nail biting', 'Impulse control disorders', 'Major depressive disorder', 'Catatonia' and 'Negative symptoms of Schizophrenia'. The psychiatric/neuropsychiatric conditions mentioned in 'Charaka Indriya sthana' are characterized by poor prognosis, having irreversible underlying pathology, chronic, progressive and debilitating in nature and commonly found in dying patients or at the endof-life stages. It seems that psychiatric conditions mentioned in 'Charaka Indriya sthana' have clinical applicability and prognostic significance in present era also. Further studies are required to substantiate the clinical findings described in 'Charaka Indriya sthana'.
\end{abstract}

Keywords: Charaka samhita, delirium, dementia, Indriya sthana, neuropsychiatric disorders, scizhophrenia
Volume 8 Issue 5 - 2020

\author{
Kshama Gupta, Prasad Mamidi \\ Professor, Department of Kayachikitsa, SKS Ayurvedic Medical \\ College \& Hospital, India
}

\author{
Correspondence: Kshama Gupta, Professor, Dept of \\ Kayachikitsa, SKS Ayurvedic Medical College \& Hospital, \\ Mathura, Uttar Pradesh, India, Tel 7567222309, \\ Email drkshamagupta@gmail.com
}

Received:September 16,2020| Published: October 12, 2020
Abbreviations: CSD, cognitive spectrum disorder; MCI, mild cognitive impairment; BPSD, behavioural and psychological symptoms of dementia; DSM-V, diagnostic and statistical manual of mental disorders- $5^{\text {th }}$ edition; NCD, neurocognitive disorder; $\mathrm{AD}$, alzheimer's disease/alzheimer's dementia; $\mathrm{VaD}$, vascular dementia; DLB, dementia with Lewy bodies; FTLD, frontotemporal lobar dementia; HD, huntington's disease; CJD, creutzfeldt-Jakob disease; HIV, human immunodeficiency virus; AIDS, acquired immunodeficiency syndrome; MS, multiple sclerosis; MSA, multiple system atrophy; $\mathrm{PD}$, parkinson's disease; PWS, prader-willi syndrome; ESP, extrasensroy perception; NDs, neurodegenerative diseases; PSP, progressive supranuclear palsy; ALS, amyotrophic lateral sclerosis; PCA, posterior cortical atrophy; TBI, trauamatic brain injury; TIA, transient ischemic attack; VCI, vascular cognitive impairment; FTD, frontotemporal dementia; VP, vascular parkinsonism; CBD, corticobasal degeneration; OGC, oculogyric crisis; PDD, parkinson's disease dementia; CP, cancer pain; CIBP, cancer induced bone pain; CNS, central nervous system; SD, seborrheic dermatitis; CBS, charles bonnet syndrome; OBS, organic brain syndrome; MDD, major depressive disorder; CS, cotard's syndrome; TTM, trichotillomania; TS, tourette's syndrome; OCD, obsessive compulsive disorder; BFRB, body focused repetitive behaviours; ADHD, attention-deficit/ hyperactivity disorder; SIB, self injurious behaviour; MRI, magnetic resonance imaging; KBS, kluver-bucy syndrome; ICU, intesive care unit

\section{Introduction}

Charaka Samhita is the oldest and most authentic treatise on Ayurveda (an ancient Indian system of medicine). ${ }^{1}$ Indriya sthana (prognostic medicine) is one among the eight sections of Charaka samhita and it deals with prognostic aspects. Indriya sthana contains 12 chapters and various 'Arishta lakshanas' are explained in 'Indriya sthana'. Arishta lakshanas are the signs and symptoms which indicates imminent death. Conditions which are having poor prognosis, having irreversible underlying pathology, conditions which are refractory to treatment, chronic, debilitating and progressive conditions, diseases having higher mortality risks, conditions which are commonly found during end-of-life stages and conditions which require hospice or palliative care etc are explained in 'Indriya sthana'.

Physician should be alert to identify the arishta lakshanas whenever they appear, incorporate them in calculating remaining life expectancy and also in clinical decision making. ${ }^{2}$ Various psychiatric and neuropsychiatric conditions are mentioned throughout 'Charaka Indriya sthana' in a scattered form. ${ }^{3-14}$ Various concepts of 'Charka samhita' were untouched or unexplored till date. The present study attempts to screen various references pertaining to psychiatric and neuropsychiatric conditions of 'Charaka Indriya sthana' and explore their rationality, clinical and prognostic significance in present era. Dementia, Delirium (Table 1) and neuropsychiatric conditions (Table 2) of 'Charaka Indriya sthana' have been explored in the following sections. 
Table I Dementia \& Delirium in Charaka indriya sthana

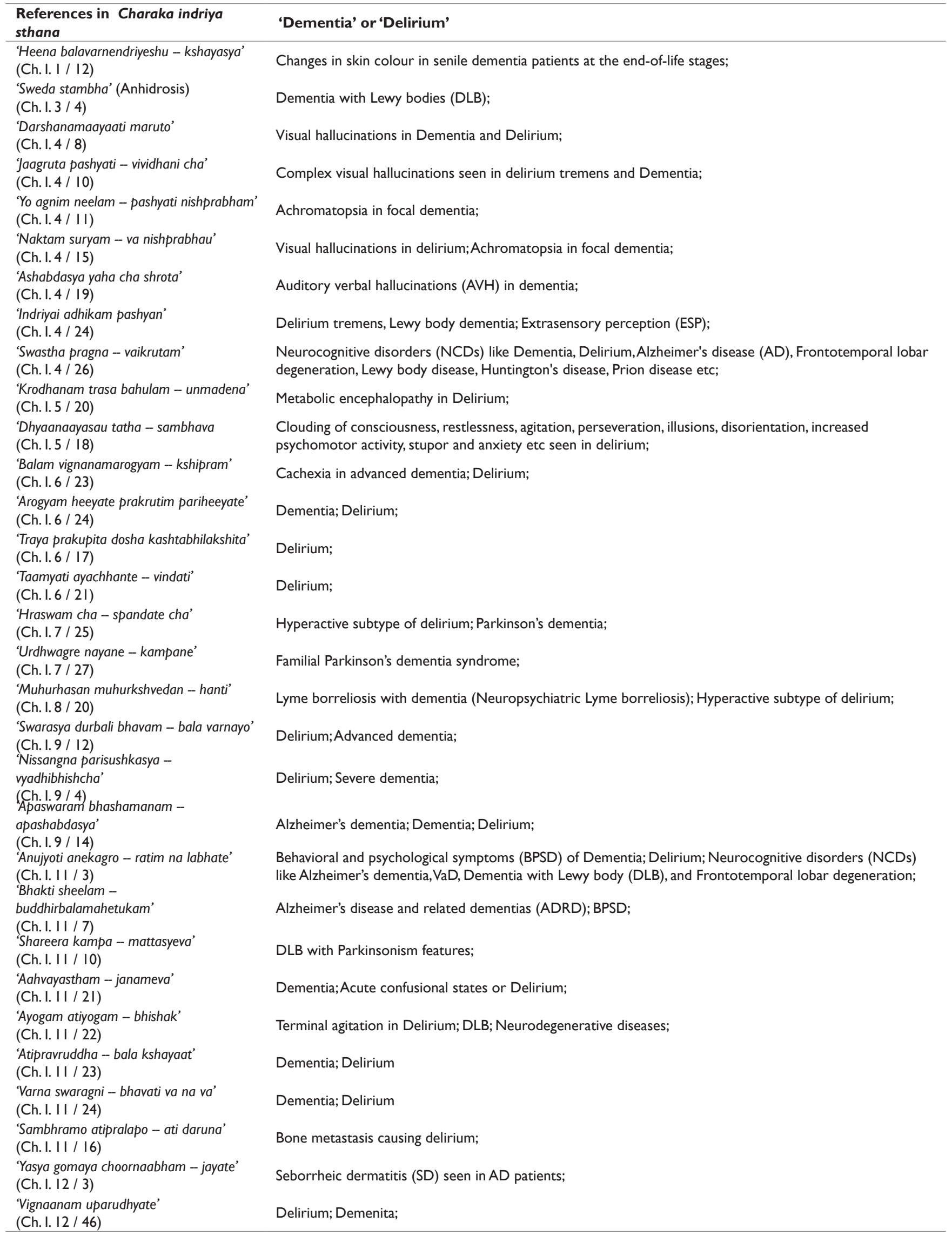


Table continue

\begin{tabular}{ll}
\hline $\begin{array}{l}\text { References in Charaka indriya } \\
\text { sthana }\end{array}$ & 'Dementia' or 'Delirium' \\
\hline 'Indriyani vinashyanit - bhajate satvam' & Dementia; Delirium; \\
(Ch. I. I 2 / 47) & \\
'Smriti tyajati - chapasarpata' & FTD;AD; \\
$\begin{array}{l}\text { (Ch. I. I } 2 \text { / 48) } \\
\text { 'Shabda sparsho - ashubhani eva' }\end{array}$ & Senile dementia; BPSD; \\
(Ch. I. I 2 / 58) &
\end{tabular}

(Ch. I. XX /YY): Ch - Charaka samhita; I - Indriya sthana; XX - Chapter number;YY - Verse number

\section{Review methodology}

Ayurvedic literature regarding 'Indriya sthana' has been collected from Charaka samhita, including 'Ayurveda dipika' commentary by Chakrapani. Electronic databases 'Google' and 'Google scholar' have been searched to find out the relevant studies and reviews based on dementia, delirium, psychiatric and neuropsychiatric conditions published till 'August 2020', irrespective of their appearance/publication year. The key words used for search were, 'Charka samhita', 'Indriya sthana', 'Charaka indriya sthana', 'Neuropsychiatric disorders', 'Dementia', 'Delirium', 'Catatonia', 'Negative symptoms of schizophrenia', 'Anxiety', 'Depression', 'Bruxism', 'Impulse control disorders', 'Trichotillomania', 'Neurocognitive disorders' 'Health psychology', 'Positive psychology', 'Psychoneuroimmunology', 'Personality factors',
'Visual allucinations', 'Auditory hallucinations', 'Cognitive distortions', 'Cognitive bias', 'Cognitive errors', 'Parkinsonism', and other relevant terms. Abstracts, full texts and open access articles in 'English language' were only considered.

\section{Psychiatric conditions}

'Dementia' and 'Delirium' are the two most common conditions found through out 'Charaka indriya sthana' (Table 1). Various references related to other psychiatric and neuropsychiatric conditions like, 'Hallucinations', 'Trichotillomania', 'Bruxism', 'Nail biting', 'Impulse control disorders', 'Major depressive disorder', 'Catatonia'. 'Negative symptoms of Schizophrenia' are also mentioned in 'Charaka Indriya sthana' (Table 2). Dementia, Delirium and neuropsychiatric conditions are explored in the following sections.

Table 2 Psychological \& Psychiatric conditions in Charaka indriya sthana

\section{References in Charaka indriya sthana}

\section{Relevant psychopathology}

\section{Psychological concepts:}

'Sattvam, bhakti, shaucham, sheelam, achara, smrti, medha, harsha, tandra \& Swapna darshana (Ch. I. I / 3)

Jati prasakta, Kula prasakta, desha, kaala vayo anupatini \& Pratyatma niyata (Ch. I. I / 5)

'Mithyadrushtam -- pragnaaparadhajam'(Ch. I. 2 / 6)

'Manovahaanaam - shubham phalam'(Ch. I. 5 / 4I-46)

'Svaachaaram, hrushtam, avyangam \& Avyagram' (Ch. I. 12 / 67-70)

Various psychological or psychiatric factors having significance

in clinical prognostication;

Various factors which influences the development of personality;

Cognitive distortions, Cognitive errors, Cognitive biases;

Physiology and classification of dreams;

Positive attributes of a caregiver;

'Sattva lakshana - shubha lakshana'(Ch. I. I 2 / 87-88)

Health psychology; Positive psychology;

\section{Hallucinations:}

'Swasthebhyo vikrutam - maranasya tat'(Ch. I. 4 / 5)

‘Ghaneebhutamiva - marana mruchhati’(Ch. I. 4 / 7)

'Yasya darshanam - kshayamaadishet'(Ch. I. 4 / 8)

'Jagruta pashyati - jeevitu marhati'(Ch. I. 4 / I0)

'Mareechi nasato - marana mruchhati'(Ch. I. 4 / I2)

‘Aparvani yada - tasya jeevitam'(Ch. I. 4 / I4)

'Naktam suryam - marana mruchhati' (Ch. I. 4 / I5)

‘Ashabdasya cha - vijaanataa' (Ch. I. 4 / I6-19)

‘Indriyai adhikam pashyan’ (Ch. I. 4 / 24)

'Indriyaanaamrute - na sa jeevati’ (Ch. I. 4 / 25)

'Laksha rakta - neeyate' (Ch. I. 5 / I0)

'Apaswaram bhashamaanam -- parivarjayet' (Ch. I. 9 / I4)

'Ayogam atiyogam va - naavachaarayet' (Ch. I. I I / 22)
Hallucinations; Illusions;

Visual hallucinations; Visual illusions;

Visual hallucinations;

Visual hallucinations:

Visual hallucinations;

Visual hallucinations;

Visual hallucinations;

Auditory hallucinations;

Hallucinations;

Hallucinations;

Visual hallucinations;

Auditory hallucinations;

Visual hallucinations; 
Table continue

References in Charaka indriya sthana

Relevant psychopathology

Psychological concepts:

Catatonia \& Schizophrenia:

\begin{tabular}{ll}
\hline 'Ahara dveshinam - ati paatinaa' (Ch. I. 5 / 19) & Catatonia; \\
'Yairvindati pura - maranamaadishet' (Ch. I. 8 / 21) & $\begin{array}{l}\text { Negative symptoms of Schizophrenia; Major depressive } \\
\text { disorder; Cotard syndrome; }\end{array}$
\end{tabular}

'Yairvindati pura - maranamaadishet' (Ch. I. 8 / 21) disorder; Cotard syndrome;

Bruxism \& Trichotillomania:

'Dantai chhindanti - parimuchyate' (Ch. I. 8 / I8)

Trichotillomania; Nail biting;

'Dantaan khaadati - vimuchyate’ (Ch. I. 8 / 19)

Bruxism;

'Pramuhya lunchayet - kaalachodita' (Ch. I. I I / I7)

Trichotillomania;

\section{Nightmares:}

'Drushyante daaruna - udeeryate' (Ch. I. 12 / 59)

Nightmares;

(Ch. I. XX /YY): Ch - Charaka samhita; I - Indriya sthana; XX - Chapter number;YY - Verse number

\section{Dementia \& delirium}

Dementia and delirium are two major causes for cognitive impairment in later years of life. Though these two conditions are distinct, mutually exclusive entities, it can be difficult at times to differentiate between them. Delirium in late life is often superimposed on pre-existing dementia and dementia is the leading risk factor for delirium in older persons. Occurrence of delirium in turn is a risk factor for subsequent development of dementia in older people without pre-existing dementia. ${ }^{[15]}$ People with various individual 'Cognitive spectrum disorders' (CSDs) (dementia, delirium, delirium superimposed on dementia and unspecified cognitive impairment) have been shown to have a high mortality in many studies internationally. Mortality post-admission is high in older people with CSD. Immediate risk is highest in those with delirium, while dementia or unspecified cognitive impairment is associated with medium- to long-term risk. ${ }^{16}$

Dementia is a clinical syndrome characterized by progressive decline of cognition that interferes with the ability to function independently. Symptoms of dementia are gradual, persistent and progressive in nature. Patients with dementia experience changes in cognition, function and behaviour. The clinical presentation of dementia is variable among individuals, and the cognitive deficits it causes can present as memory loss, communication and language impairments, agnosia, apraxia and impaired executive function such as reasoning, judgement and planning. Patients with mild deficits who do not meet the criteria for dementia are considered to have mild cognitive impairment (MCI). Behavioural and psychological symptoms of dementia (BPSD) are complications of dementia. Wandering, hoarding, inappropriate behaviours such as sexual disinhibition and eating inappropriate objects, repetitive behaviour and restlessness etc comes under BPSD which do not respond well to treatment. In the most recent 'Diagnostic and Statistical Manual of Mental Disorders (DSM-V)', the term 'Neurocognitive disorder' (NCD) was introduced and replaced the term 'Dementia'. The NCD is classified as mild or major, (based on the severity of symptoms). ${ }^{17}$ The most common types of dementia are Alzheimer's disease $(\mathrm{AD})$, vascular dementia $(\mathrm{VaD})$, dementia with Lewy bodies
(DLB) and frontotemporal lobar dementia (FTLD). Less common causes of dementia include Huntingdon's disease (HD), CreutzfeldtJakob disease (CJD), Human immunodeficiency virus (HIV) / Acquired immunodeficiency syndrome (AIDS) and multiple sclerosis (MS). ${ }^{18}$

Delirium is an acute, transient and usually reversible neuropsychiatric syndrome, seen in medical-surgical set-ups. It is considered as a serious problem in acute care settings and it reflects decompensation of cerebral functions due to the result of one or more underlying pathophysiological processes. ${ }^{19}$ The clinical presentation of delirium is variable and it is classified broadly into three subtypes, hypoactive, hyperactive and mixed (based on psychomotor behavior). Patients with hyperactive delirium demonstrate features of restlessness, agitation, hyper vigilance, hallucinations and delusions. Patients with hypoactive delirium present with lethargy and sedation, respond slowly to questioning, and show little spontaneous movement. Patients with mixed delirium demonstrate both hyperactive and hypoactive features. ${ }^{20} \mathrm{~A}$ variety of terms have been used in the literature to describe delirium, such as "acute confusional state," "acute brain syndrome," "acute cerebral insufficiency," and "toxicmetabolic encephalopathy". Delirium is characterized by a rapid onset of symptoms, fluctuating course and an altered level of consciousness, global disturbance of cognition or perceptual abnormalities, and evidence of a physical cause. ${ }^{21}$

\section{References of Dementia \& Delirium in Charaka indriya sthana}

\section{'Heena balavarna --- kshayasya bhavati' (Verse 12)}

According to the above verse, reduced energy, body complexion and performance of sensory organs denote imminent death. Lack of self esteem, Apathy (diminished interest), slowing and lack of energy (heena bala) and anhedonia (lost of interest in previous pleasurable stimuli) etc emotional disturbances can be seen in dementia patients. ${ }^{22}$ Hearing loss, visual impairment, olfactory loss, and dual sensory impairments (heena indriyeshu) are related to cognitive declination and neurodegenerative disorders. Sensorineural organ impairment (heena indriyesh $u$ ) is a predictive factor for mild cognitive impairment 
and neurodegenerative disorders (dementia) in the elderly. ${ }^{23}$ Vital power decline, body weight reduction (heena bala) and changes in skin colour (heena varna) are some of the signs and symptoms of impending death in end-of-life (ayusha kshayasya) senile dementia patients. $^{24}$

\section{'Sweda stambha' (Verse 4)}

The above condition denotes 'Anhidrosis'. Anhidrosis (sweda stambha) is more widespread in 'Multiple system atrophy' (MSA) than in 'Parkinson's disease' (PD). DLB is another form of synucleinopathy that usually presents as distal anhidrosis (sweda stambha). Apart form degenerative diseases, structural lesions such as stroke, MS, tumors, and infection can also cause anhidrosis (sweda stambha) when they involve autonomic pathways. ${ }^{25}$

\section{'Darshanamaayaati maruto' (Verse 8)}

According to the above verse, visualization of the flow of wind (in the absence of ophthalmic pathology) denotes imminent death. Visual hallucinations (darshanam maruto) are the most common type of hallucination seen in delirium patients. A strong positive correlation between visual hallucinations and the number of active somatic diagnoses has been established. Delirium from alcohol withdrawal (i.e., delirium tremens) or stimulant intoxication is typically accompanied by visual hallucinations. The visual hallucinations in DLB involve seeing objects move when they are actually still (darshanam maruto) and seeing complex scenarios of people and items that are not present. Visual hallucinations are an important clinical clue indicating DLB rather than with another subtype of dementia. Posterior cortical atrophy is another neurodegenerative syndrome associated with visual hallucinations (darshanam maruto). ${ }^{26}$

\section{'Jaagruta pashyati --- sa jeevitumarhati' (Verse 10) ${ }^{6}$}

The above verse denotes 'Complex visual hallucinations'. Visual hallucinations (jaagruta pashyati) in delirium tremens typically involve different types of animals (dogs, cats, snakes, insects, rats) or signs and shapes (multicolored patterns, chalk writing on slate). Tactile, auditory, musical and lilliputian hallucinations (anyad vaa api adbhutam) may also occur in delirium tremens. Hallucinations in $\mathrm{AD}$ are visual (jaagruta pashyati), although auditory, tactile and olfactory hallucinations have also been observed. Well-formed visual hallucinations (jaagruta pashyati) are seen in DLB patients. The hallucinatory experiences in PD patients may include sensations of presence of people or animals (jaagruta pashyati) and feeling of floating (anyad vaa api adbhutam). ${ }^{27}$

\section{'Yo agnim prakruti --- vrajati saptameem' (Verse 11) ${ }^{6}$}

The above verse denotes 'Achromatopsia' or 'Dyschromatopsia'. Dysfunction in different tasks of vision and visual cognition, decreased visual acuity (pashyati nishprabham), visuospatial disorientation, deficits in visual motion perception, contrast sensitivity disturbances and incomplete achromatopsia (krishnam va shuklam va pashyati) etc are the pathological alterations of the visual system caused by AD. Dementia, including AD, is a major disorder, leading to several ocular manifestations amongst the elderly population..$^{28}$

\section{'Naktam suryam --- maranamruchhanti' (Verse 15) ${ }^{6}$}

The above verse indicates visual illusions, hallucinations and achromatopsia. 'A perception without an object' is the classic definition of a hallucination and a visual hallucination is experienced when one sees something where nothing actually exists (anagnau dhoomamuthitam). Patients with dementia with Lewy bodies frequently experience a variety of visual illusions as well as visual hallucinations (naktam suryam pashyati aha chandram). Various visuoperceptual dysfunctions like visual illusions and hallucinations etc are seen in AD and DLB. ${ }^{29}$ Visual hallucinations can be seen in occipital seizures, migraines, ocular pathology, Charles Bonnet syndrome (CBS), narcolepsy, psychosis, and delirium. ${ }^{30}$

\section{'Ashabdasya yaha --- vijaanataa'(Verse 19)}

The above verse denotes 'Auditory hallucinations' and 'Auditory agnosia'. Auditory agnosia (shabdaan yascha na budhyate) can be seen in various neurodegenerative diseases such as AD. ${ }^{31}$ Auditory agnosia or word defaness and cortical defaness (shabdaan yascha na budhyate) are seen in dementia patients. Patients with semantic dementia develop deficits of nonverbal sound recognition (auditory associative agnosia) (shabdaan yascha na budhyate). Impaired recognition of familiar voices (shabdaan yascha na budhyate) may be a salient symptom of right temporal lobe degeneration. Elementary auditory hallucinations (ashabdasya yaha cha shrota) are seen in 'Semantic dementia'. Hallucinations of 'muffled' sounds or voices (Ashabdasya yaha cha shrota) are seen in DLB patients. ${ }^{32}$ 'Shabdaan yascha na budhyate' or auditory agnosia is similar to 'Shroto buddhi vibhrama'.33

\section{'Indriyai adhikam --- adhigachhati' (Verse 24) ${ }^{6}$}

The above verse denotes 'Hallucinations' or 'Extrasensory perception'. Conditions causing interference with or damage to the peripheral sensory pathways can produce hallucinations (indriyai adhikam pashyan). Hallucinations can also be seen in conditions like thyroid dysfunctions, Hashimoto disease, deficiencies in vitamin $\mathrm{D}$ and $\mathrm{B}_{12}$, Prader-Willi syndrome (PWS), autoimmune disorders, HIV/AIDS, narcolepsy, tumors, traumatic brain injuries, epilepsy, cardiovascular events involving the brainstem regions and temporal, occipital, or temporo-parietal pathways, neurodegenerative conditions such as PD and DLB. ${ }^{34}$ The ESP (extrasensory perception) (indriyai adhikam pashyan) or paranormal experiences include 'telepathy' (communication between two geographically separated persons, outside the range of sensory organs), 'clairvoyance' (knowledge of hidden objects or events occurring outside the physical reach of the person) and 'precognition' (knowledge of future events that can not be predicted or inferred from the available information). ${ }^{35}$ Achieving ESP in the absence of 'Yogic practices' denotes imminent death as per the above verse.

\section{'Swastha pragna --- maranamaadishet' (Verse 26) ${ }^{6}$}

The above verse denotes cognitive alterations or disturbances or distortions due to an underlying pathology. Cognitive disturbances or alterations (pragna viparyaya) are seen in 'Neurodegenerative diseases' (NDs) such as AD, DLB, FTLD, PD and other neurological conditions like progressive supranuclear palsy (PSP), amyotrophic lateral sclerosis (ALS), posterior cortical atrophy (PCA), corticobasal syndrome, ischemic or hemorrhagic stroke, transient ischemic attack (TIA) and traumatic brain injury (TBI) etc. ${ }^{36}$ Vascular cognitive impairment (VCI) defines alterations in cognition (pragna viparyaya), ranging from subtle deficits to full-blown dementia, due to cerebrovascular causes. Mixed vascular and neurodegenerative dementia comorbid with $\mathrm{AD}$ has emerged as the leading cause of agerelated cognitive impairment. ${ }^{37}$

\section{'Krodhanam --- unmado sharirinaam'(Verse 20)'}

Panic attacks are characterized by severe apprehension (trasa bahulam), dizziness (murcha), chest discomfort, palpitations, or fear of "losing control." Intermittent loss of consciousness (murcha) may suggest 'Syncope' which occurs due to global cerebral hypoperfusion. ${ }^{38}$ 
Agitation, restlessness, hypervigilance (traasa bahulam), delusions, hallucinations, disturbance of consciousness (murcha), dehydration (due to intercurrent illness) (pipaasa bahulam), and behavioral changes (krodhana \& prahasitaanana) can be seen in delirium. ${ }^{20}$ The above verse denotes delirium.

\section{'Dhyaanaayasau --- unmada purvaka'(Verse 18)'}

The etiologies of delirium are diverse and multi-factorial, and they often reflect the pathophysiological consequences of an acute medical illness. Delirium develops through a complex interaction between different risk factors. Hypervigilance (dhyaana), emotional distress (adyaasa), agitation (udvega), restlessness (arati), disturbance of consciousness (moha), and energy deprivation (due to metabolic derangements) (bala haani) etc are seen in delirium. ${ }^{20}$ The above verse indicates delirium.

\section{'Balam vignanam --- kshipram sa hanyate' (Verse 23) ${ }^{8}$}

Cachexia is a complex metabolic process associated with underlying terminal illnesses (sa hanyate) and it is characterized by anorexia (ksheeyante grahani) and loss of fat and muscle mass (ksheena mamsa). Loss of body weight and reduced energy levels (bala haani) are also found in cachexia. Cachexia is known to be associated with advanced dementia (vignanam ksheeyate). The natural history of dementia spans over 10 years, and the later stages of the disease are marked by substantial unintentional weight loss (bala haani), malnutrition (ksheeyante grahani), sarcopenia (ksheena mamsa), anorexia (ksheeyante grahani), lethargy (bala haani), altered immune function (ksheeyante arogyam), and cachexia. ${ }^{39}$ The above verse indicates cachexia in advanced dementia patients.

\section{'Arogyam heeyate --- harati jeevitam' (Verse 24) ${ }^{8}$}

Psychological symptoms and behavioral abnormalities (prakrutim pariheeyate) such as depression, anxiety psychosis, agitation, aggression, disinhibition, and sleep disturbances etc are common and prominent characteristics of dementia. Personality changes (prakrutim pariheeyate) are most common in $\mathrm{AD}$. Early loss of personal and social awareness, early decline in social interpersonal conduct, early loss of insight, and emotional blunting are characteristic features of 'Frontotemporal dementia' (FTD) (prakrutim pariheeyate). Health related quality of life and ability to perform activities of daily living (arogyam heeyate) are also impaired in dementia patients..$^{40}$ The above verse denotes advanced stages of dementia or delirium.

\section{'Traya prakupita --- nasti tasya chikitsitam' (Verse 17) ${ }^{8}$}

Delirium is common in the last weeks of life (nasti tasya chikitsitam), occurring in $26 \%$ to $44 \%$ of people with advanced cancer in hospital, and in up to $88 \%$ of people with terminal illness in the last days of life (nasti tasya chikitsitam). Delirium is part of a wide range of organic mental disorders that includes dementia, organic mood disorder, and organic anxiety disorder. The prognosis of terminal illness (traya prakupita dosha kashtabhilakshita) is worsened by delirium. ${ }^{41}$ The above verse denotes chronic, debilitating, fatal, and terminal illness which leads to delirium and death.

\section{'Taamyati ayachhante --- achiraannara' (Verse 21) ${ }^{8}$}

The above verse denotes delirium due to an underlying terminal illness or delirium superimposed on advanced dementia patients with cachexia. Disturbance or clouding of consciousness (taamyati), agitation (sharma na vindati kinchidapi), restlessness (sharma na vindati kinchidapi) and increased psychomotor activity (aayachhate) are seen in delirium. ${ }^{20}$ During last days of life patients often experience progressive functional decline and worsening symptom burden. Many symptoms such as anorexia-cachexia (ksheena ahara \& ksheena mamsa), weight loss (ksheena bala), decreased quality of life and delirium can be found in last days of life. ${ }^{42}$

\section{'Hraswam cha --- punarvasu' (Verse 25) ${ }^{9}$}

The above verse denotes either delirium (hyperactive subtype) or seizures. Respiratory impairment (hraswam prashvasati) can be found in delirium patients. Delirium can be accompanied by overactivity of the autonomic system, producing sweating, pupil dilatation, and tremor (vyaviddham spandate). Delirium may carry a high morbidity and mortality (mrutameva tam). Seizures (vyaviddham spandate) may present with ictal, interictal, or postictal delirium. Many of the conditions resulting in delirium may also induce seizures (vyaviddham spandate) such as hepatic and renal failure, electrolyte and metabolic abnormalities, drug intoxications, intracranial infections, and acute cerebrovascular events. ${ }^{43}$

\section{'Urdhwagre nayane --- na sa jeevati'(Verse 27)}

Vascular parkinsonism (VP) is a condition which presents with the clinical features of parkinsonism that are presumably caused by cerebrovascular disease. Diagnosis is supported by the history of prior stroke and vascular risk factors such as hypertension, diabetes mellitus, hypercholesterolemia, or carotid stenosis (manya arata kampane?). ${ }^{44}$ The parkinsonian syndromes include idiopathic PD, PSP, MSA, corticobasal degeneration (CBD) and VP. ${ }^{45}$ Oculogyric crises (OGC) (urdhwagre nayane yasya) are defined as spasmodic movements of the eyeballs into a fixed position, usually upwards. OGC (urdhwagre nayane yasya) can be seen secondary to different neurological conditions such as neurotransmitter disorders, disorders affecting certain parts of the brainstem, multiple sclerosis and encephalitis. ${ }^{46}$ OGC (urdhwagre nayane yasya) can be seen in 'Postencephalitic parkinsonism' ${ }^{47}$ Balaheena (fatigue), shushkaasya (dry mouth), and pipaasa (excessive thirst) indicates dehydration or hypovolemia. The above verse denotes a condition of OGC with an underlying stroke or cerebrovascular pathology.

\section{'Muhurhasan --- na sa jeevati' (Verse 20) ${ }^{10}$}

BPSD also termed as 'Neuropsychiatric symptoms', occur in most patients with dementia. They describes the heterogeneous group of signs and symptoms of disturbed perception, thought content, mood (muhurhasan) or behaviour that frequently occur in patients with dementia. ${ }^{48}$ Aggressive behaviours such as verbal agression (screaming and cursing), physical aggression (hitting, biting, kicking, scratching and grabbing) (shayyaan paadena hanti), mannersisms (uchhai chhidraani vimrushyan), mood disturbances (anger outbursts, irritability, anxiety and depression), delusions, hallucinations and illusions etc are the common behavioural disturbances seen in dementia patients. Late-life dementias are associated with delusions and hallucinations (muhurhasan). Disruptive vocalization (muhurkshvedan) tends to occur along with various other agitated behaviors. ${ }^{49}$ Emotional disturbances (muhurhasan), such as anxiety, fear, irritability, anger, depression, and euphoria are seen in delirium patients. Delirium patients show features such as hyper-vigilance, restlessness, agitation, aggression (shayyaan paadena hanti), mood lability (muhurhasan), and in some cases, hallucinations and delusions. Behaviors are frequently disruptive (e.g., shouting or resisting, pulling out the IV tubing) or potentially harmful (shayyaan paadena hanti). ${ }^{21}$ The above verse denotes BPSD features of dementia or hyperactive subtype of delirium. 


\section{'Swarasya durbali --- maranamaadishet'(Verse 12)}

Decline in vital power (bala haani), changes in skin colour (skin becomes deadly pale, earth like colour, and turns white) (varna haani), and weight loss etc are the signs and symptoms of death in end-of-life (maranam) senile dementia patients. ${ }^{24}$ Hypophonia (swarasya durbali bhaava) is seen in late stage PD. ${ }^{50}$ Delirium is a common and serious disorder with high morbidity and mortality ${ }^{51}$ Delirium is prevalent at the end of life (maranam), particularly during the final 24-48 hours. Delirium is characterised by rapidly emerging (rogavriddhi ayuktya) disturbance of consciousness and a change in cognition with fluctuating symptoms and evidence of organic aetiology. ${ }^{52}$ The above verse denotes terminal illnesses, advanced dementia and delirium.

\section{'Nissangna --- dheera parivarjayet' (Verse 4) ${ }^{11}$}

Disturbances or clouding of consciousness (nissangna) is one of the characteristic features of delirium. Delirium is highly prevalent in the elderly and those with serious or advanced medical illnesses (samruddho vyadhibhishcha). It is associated with many adverse consequences (uparuddha ayusham). Delirium often leads to increased need for higher levels of care, functional decline, increased mortality, and decreased life expectancy (uparuddha ayusham). ${ }^{53}$ Delirium is multifactorial in origin, and precipitating or contributory factors include dehydration and hypovolemia (parisushkasya) ${ }^{54}$ The above verse denotes delirium with hypovoemia.

\section{'Apaswaram --- doorata parivarjayet'(Verse 14) ${ }^{11}$}

The above verse denotes abnormal vocalizations or speech and auditory hallucinations seen in PD, dementias, and in delirium. Auditory hallucinations (shrotaaram ashabdasya) are common neuropsychiatric symptoms in DLB ${ }^{55}$ Vocalizations (apaswaram bhashamanam) consist of excessively loud and repetitive verbal utterances, such as single words or phrases, nonsensical sounds, screaming, moaning, and constant requests for attention. Nearly all disruptive vocalizations are related to a form of brain injury; most have dementia due to $\mathrm{AD}$ or cerebrovascular disease. ${ }^{56}$ Auditory hallucinations (shrotaaram ashabdasya) can be seen in AD patients. ${ }^{57}$

\section{'Anujyoti anekagro --- samaantaram'(Verse 3) ${ }^{13}$}

BPSD include agitation (anekagro), aberrant motor behavior, anxiety (anekagro), elation, irritability (durmana), depression, apathy, disinhibition, delusions, hallucinations, and sleep or appetite changes (anu jyoti). BPSD is associated with poor outcomes (yaati paralokam), and distress (durmana) to patients. ${ }^{22}$ Changes in skin colour (skin becomes deadly pale, earth like colour, and turns white) (dushchhaya) is one of the the signs and symptoms of death in end-of-life (yaati paralokam) senile dementia patients..$^{24}$ Reduced appetite (anu jyoti) is one of the sickness features caused by inflammatory response in delirium patients. ${ }^{58}$ Delirium patients show features such as hypervigilance (anekagro), restlessness (ratim na labhate), agitation, aggression (durmana), mood lability (durmana), and in some cases, hallucinations and delusions (durmana). ${ }^{21}$ The above verse denotes dementia or delirium.

\section{'Bhakti sheelam --- marishyata'(Verse 7) ${ }^{13}$}

AIthough cognitive decline (buddhi \& smriti nivartante) and deficits in social competence (sheelam or bhakti nivartante) are the hallmarks of progressive neuro-degeneration, behavioral abnormalities (sheelam or bhakti nivartante) are common and important characteristics of dementia. Personality changes such as disinterest (bhakti nivartante), in environment or inappropriate social behavior (sheelam nivartante) are most common in AD. Various behavioural and personality changes and BPSD features (bhakti, smriti, buddhi \& sheelam etc nivartante) can be seen in AD, FTD, DLB and other dementia syndromes. ${ }^{40}$ The above verse denotes various dementia syndromes.

\section{'Shareera kampa --- masam na jeevati'(Verse 10) ${ }^{13}$}

The above verse indicates PD dementia (PDD) or delirium superimposed on preexisting dementia. The classical motor features of PD include rigidity, resting tremor (kampa), bradykinesia and postural instability (mattasyeva gati). Language abnormalities (mattasyeva vachana) are also seen in dementia. 'Associated clinical features' of PDD are defined along four primary cognitive domains (attention, memory, executive and visuo-spatial functions) (sammoha) and a spectrum of behavioural disorders ${ }^{59}$ Confusion (sammoha), gait instability (mattasyeva gati), language deficits (although most commonly seen in AD) (mattasyeva vachana) and cognitive deterioration are seen in PDD. ${ }^{60}$

\section{'Aahvayastham --- na pashyati' (Verse 21$)^{13}$}

The above verse denotes dementia or delirium. Cognitive symptoms (mahamohavruta mana) in AD include memory loss (poor recall, losing items), aphasia, agnosia (pashyannapi na pashyati), apraxia, disorientation features such as impaired perception of time and unable to recognize familiar people (pashyannapi na pashyati) and impaired visuospatial function and executive function. ${ }^{17}$ Face recognition is significantly affected (swajanam janameva pashyannapi na pashyati) in patients with FTD. Prosopagnosia in AD is of visuospatial nature and hence can recognize the individual when named or spoken to, but in FTD, it is multimodal and hence cannot be recognized by any mode (pashyannapi na pashyati). ${ }^{61}$ Synonymous equivalents of the term delirium are, "acute brain syndrome," "organic brain syndrome," "acute cerebral insufficiency," "acute confusional state," "disorders of consciousness," "transitional syndrome," and "confusional syndrome" (mahamohavruta mana). ${ }^{62}$

\section{'Ayogam atiyogam --- naavachaarayet' (Verse 22) ${ }^{13}$}

The above verse denotes 'Sensory impairments', 'Agnosia', and 'Hallucinations' seen in dementia and delirium. Agnosia (ayogam), communication and language impairments and hallucinations (atiyogam) can be seen in various sub types of dementia such as $\mathrm{AD}$, DLB, FTD and VaD. ${ }^{17}$ Sensory impairments (ayoga) are one of the potential modifiable risk factor for delirium. Patients with hyperactive subtype of delirium often experience delusions and hallucinations (atiyoga). ${ }^{20}$

\section{'Atipravruddha --- deha sangnakam'(Verse 23)}

The above verse denotes delirium or advanced dementia. Patients at the end of life (vaasamutsrujati) develop a number of distressing symptoms. Delirium is one of the most common neuropsychiatric problems (manasashcha balakshayaat) in patients with advanced cancer and other terminal illnesses (atipravruddha rogaanaam). ${ }^{52}$ Dementias are progressive and incurable diseases (atipravruddha rogaanaam). People with advanced dementia develop apraxia, dysphagia, and decreased mobility, thus increasing the risk of infection, malnutrition, and other adverse outcomes (atipravruddha rogaanaam). Therefore, advanced dementia (manasashcha balakshayaat) should be considered a terminal illness, particularly at the very severe or end-stage state (vaasamutsrujati). ${ }^{63}$

\section{'Varna swaragni --- va na va' (Verse 24) ${ }^{13}$}

Delirium is an acute and fluctuating disturbance of consciousness and cognition, is a common manifestation of acute brain dysfunction 
(heeyate manobalam) in critically ill patients (aasu kshaye), occurring in up to $80 \%$ of the sickest intensive care unit (ICU) populations (aasu kshaye). Altered level of consciousness, inattentiveness, disorientation, psychosis, psychomotor agitation or retardation (heeyate manobalam), inappropriate speech (heeyate vaak balam) or mood and sleep-wake cycle disturbances (sleeping $<4$ hours / day or waking at night or sleeping all day) (nidraa nityaa va na va) are seen in delirium in ICU patients. ${ }^{64}$ Breathing disorder, consciousness decline, vital power decline (heeyate bala), reduced oral intake (heeyate agni), feces disorder, calm and peaceful character, blood pressure decline, change in skin color (heeyate varna), patient odor, edema, preagonal vital power, body temperature decline, bedsore/wound deterioration, body weight reduction (heeyate bala), cyanosis, and oliguria are the signs and symptoms of impending death in end of life (aasu kshaye) senile dementia (heeyate vaagindriya manobalam) patients. ${ }^{24}$ The above verse denotes delirium or dementia.

\section{'Sambhramo --- pravartate' (Verse 16$)^{13}$}

Bone metastasis and advanced cancer can act as predisposing risk factors for delirium. ${ }^{65}$ Cancer pain remains a significant clinical problem worldwide. Causes of cancer pain are multifactorial and complex and are likely to vary with an array of tumor-related and host-related factors and processes.A good example of the emerging theory of 'Cancer pain' (CP) is cancer-induced bone pain (CIBP), which now is understood as a complex pain state with nociceptive but also inflammatory and neuropathic characteristics. ${ }^{66}$ Bone metastases often result in breakthrough pain episodes. ${ }^{67}$ Incoherent speech and rambling or irrelevant conversation, or unclear or illogical flow of ideas along with altered level of consciousness can be seen in delirium patients. ${ }^{21}$ The above verse denotes a condition of delirium associated with bone pain due to bone metastases.

\section{'Yasya gomaya --- tasya jeevitam'(Verse 3$)^{14}$}

Seborrheic Dermatitis (SD) and dandruff are common dermatological problems that affect the seborrheic areas of the body. Dandruff is restricted to the scalp (murdhani jaayate), and involves itchy, flaking skin (bhrashyate chaiva) without visible inflammation. SD affects the scalp (murdhani jaayate) as well as face, retro-auricular area and upper chest, causing flaking, scaling, inflammation and pruritus, and erythema. Flaking (bhrashyate chaiva) in SD and dandruff is usually white-to-yellowish (gomaya choornaabham), and may be oily (sa sneham) or dry. ${ }^{68}$ Previous studies suspect that fungal infections might be involved in central nervous system (CNS) diseases including AD, ALS, MS and schizophrenia. $\mathrm{SD}$ is a benign dermatological condition caused by over proliferation of Malassezia on the skin and it is strongly associated with PD. Recent studies have found Malassezia DNA in the CNS of MS and $\mathrm{AD}$ patients ${ }^{69}$ The above verse denotes SD or dandruff in dementia patients.

\section{'Vignaanam uparudhyate' (Verse 46) ${ }^{14}$}

Dementia and delirium are the two most common causes of cognitive impairment (vignaanam uparudhyate) in older populations. Dementia, an insidious neurodegenerative condition, is characterised by chronic and progressive cognitive decline (vignaanam uparudhyate) from a previous level of performance in one or more cognitive domains (vignaanam uparudhyate). Delirium is a syndrome manifesting as an acute change in mental status that is characterised by inattention and disturbance in cognition (vignaanam uparudhyate) that develops over a short period of time and tends to fluctuate. ${ }^{70}$ The above verse denotes cognitive impairment seen in dementia and delirium etc conditions.

\section{'Indriyaani vinashyanti --- bheeraavishatyapi' (Verse 47) ${ }^{14}$}

Along with cognitive decline and sensory impairments (indriyaani vinashyanti), various non-cognitive symptoms can be seen in dementia such as delusions, hallucinations, anxiety (cheto bheeraavishatyapi), agitation (autsukyam bhajate sattvam) and aggressive behavior. ${ }^{15}$ Sensory and cognitive impairments (indriyaani vinashyanti) is one of the risk factors for the development of delirium. Severe agitation (autsukyam bhajate sattvam), restlessness (autsukyam bhajate sattvam) and severe anxiety (cheto bheeraavishatyapi) can be seen in delirium. ${ }^{19}$ The above verse denotes conditions like dementia or delirium.

\section{'Smriti tyajati --- nashyati' (Verse 48) $)^{14}$}

Dementia is characterized clinically by progressive memory (smriti tyajati) \& orientation loss and other cognitive deficits (medha tyajati). These are typically accompanied by various neuropsychiatric symptoms (i.e. depression, apathy, anxiety, agitation, delusions \& hallucinations). Disinhibition (hree apasarpati) is one of the features of BPSD in AD. ${ }^{71}$ Older age, multimorbidity (upaplavante paapmana) and dementia are all strongly correlated with adverse health outcomes as well as a proxy for loss of independent living. ${ }^{72}$ Many modifications of immune system (ojashcha nashyati) have been reported in patients affected by AD..$^{73}$ Delirium is a complex neurocognitive manifestation (smriti tyajati medha cha) due to an underlying medical abnormality such as organ failure, infection or drug effects (upaplavante paapmana). It occurs frequently in palliative and supportive care, in patients with advanced cancer and in the terminal phase of the illness. Disturbances in cognition (medha tyajati) and memory deficits (smriti tyajati) are seen in delirium. ${ }^{74}$ Disinhibition (hree apasarpati) is also one of the features of delirium..$^{21}$ The above verse denotes advanced stages of dementia, BPSD features of dementia especially FTD and delirium in ICU patients.

\section{'Shabda sparsho --- pravruttishu' (Verse 58) $)^{14}$}

Sensory impairments such as visual impairment (rupa), hearing loss (shabda), poor smell (gandha) and touch insensitivity (sparsha) are common in older adults and also associated with increased risk of mortality and dementia. Sensory impairment may be a marker of underlying neurodegeneration. Multisensory impairment was strongly associated with increased risk of dementia. ${ }^{75}$ Presence of hallucinations (utpadyante ashubhaaneva) is selectively associated with more rapid cognitive decline in Alzheimer's disease. ${ }^{76}$ The above verse denotes multisensory impairments, BPSD features and hallucinations seen in the patients of senile dementia and dementia superimposed on delirium.

\section{Other psychiatric / neuropsychiatric conditions}

Psychiatric and neuropsychiatric conditions are explained under the domain of 'Unmada' (a broad disease consists of various psychiatric and neuropsychiatric conditions) in various Ayurvedic classical texts. Unmada is explained in 'Nidana sthana' (section which deals with etiopatholgoy) and 'Chikitsa sthana' (section which deals with treatment) in various Ayurvedic classical texts. Different types of unmada have shown similarity with various psychiatric/ neuropsychiatric conditions according to the previous works. ${ }^{77-94}$ Apart from 'Unmada', description of various psychiatric/neuropsychiatric conditions can also be found in 'Charaka indriya sthana'. ${ }^{3-14}$ The exploration of various references pertaining to psychological concepts and psychiatric / neuropsychiatric conditions in 'Charaka indriya sthana' has been done in following sections. 


\section{Psychological concepts in Charaka indriya sthana}

\section{'Sattvam, bhakti --- jignaasamaanena bhishajaa' (Verse 3$)^{3}$}

The above verse denotes varoius psychological factors such as 'Sattvam' (mind), 'Bhakti' (interests), 'Shaucham' (hygiene), 'Sheelam' (character/personality), 'Achara' (conduct), 'Smriti' (memory), 'Medha' (intellect), 'Harsha' (positive mood/elation), 'Tandra' (fatigue/hypersomnia), and 'Swapna darshana' (dreams) etc which can be used clinically to prognosticate life expectancy or to assess survival time frame in those patients who are at end of life stages or suffering with terminal illnesses or receiving palliative or hospice care. Various questionnaires, scales and other measuring instruments based on the above factors are available for clinical prognostication. ${ }^{3}$

\section{'Tatra prakruti --- visheshaa bhavanti'(Verse 5)}

The above verse denotes various factors which influences the formation and development of human personality (prakruti). Various factors such as 'Jaati' (community/cultural), 'Kula' (caste/ cultural), 'Desha' (geographical/environmental), 'Kala' (generational differences/environmental), 'Vaya' (age) and 'Pratyatma niyata' (individualized or genetic) etc influences the formation and development of personality or personality traits. Personality traits (prakruti) are commonly defined as relatively stable patterns of thoughts, feelings, and actions in which one individual differs from others (pratyatma niyata). Several studies have found that individual differences in personality traits are substantially genetically (jaati, kula and pratyatma niyata) influenced. Personality can change at every age (vaya) throughout the life span. Environmental factors (desha/kala), life events (major changes in life circumstances and social roles), cultural influences (jaati/kula), social factors (jaati/ kula), and biological factors (vaya/pratyatma niyata) etc all can influence the personality. ${ }^{[95]}$

\section{'Mithyadrushtam --- pragnaaparadhajam' (Verse 6)}

The above verse denotes cognitive distortions or cognitive errors or cognitive biases made by the physician while prognosticating. Cognitive biases (mithyadrushtam) and personality traits of the physiciain may affect clinical reasoning processes which may lead to errors in the diagnosis, management, or treatment of medical conditions. Misdiagnosis, mismanagement, and mistreatment (ajaanataa) are frequently associated with poorer outcomes. Cognitive biases (i.e., anchoring and framing effects, information biases) and personality traits (e.g. tolerance to uncertainty, aversion to ambiguity) (asambuddha) are the most commonly reported cognitive biases which may potentially affect physicians' decisions. ${ }^{96}$ Cognitive errors (pragnaaparadhajam) can be derived from 3 sources, knowledge deficits, cognitive bias and clinician attitude problems. Cognitive errors (mithyadrushtam) are the most frequent in the field of 'Emergency medicine'. 97 'Type 1' thinking is a fast, intuitive, pattern recognition driven method of problem solving, which places a low cognitive burden on the user, and allows one to make fast and accurate decisions rapidly (pragnaaparadhajam). However, this type 1 , rapid decision was poor at predicting diagnosis or aiding further prognostication (pragnaaparadhajam). ${ }^{98}$ The above verse warns the physician to be hypervigilant and to minimize or avoid cognitive biases or errors while prognosticating especially in emergency wards.

\section{'Manovahaanaam -- shubham phalam' (Verse 41-46)}

The above verses describe the physiology, classification and consequences (positive \& negative) of dreams. Oneirology is the scientific study of dreams. Ancient Indian scholars have used swapna (dreams) as a tool to diagnose a disease, to assess the prognosis of a condition, for personality assessment and also to know the life expectancy. The dream has been described from physiological, pathological, diagnostic, prognostic and therapeutic point of view in Ayurvedic texts. Ayurvedic texts have described the concepts like 'Analysis or interpretation of dreams' and also usage of dreams as a tool to prognosticate or diagnose the underlying hidden conditions. ${ }^{7}$

\section{'Svaachaaram --- avyagram' (Verse 67-70) ${ }^{14}$}

The above verse denotes various positive personality traits required for a caregiver. Tranquility (avyagram), empathy, courage (avyangam), warmth, commitment, patience (avyagram), joyfulness (hrushtam), kind-heartedness (svaachaaram), thoughtfulness, mutually-orientedness (svaachaaram) and helpfulness (svaachaaram) are considered as positive attributes of a caregiver. Patients appreciated caregivers who gave efficient help which was well thought out and reasonable. Caregivers support and assistance give patients the power and strength to move on with their lives. ${ }^{99}$

\section{'Sattva lakshana --- shubha lakshana'(Verse 87-88) ${ }^{14}$}

The above verse denotes positive personality attributes or health psychology or positive psychology. Health psychology focuses on the interplay among biological dispositions, behaviour, and social context. A biopsychosocial model considers health as the complex interplay among biological disposition, behaviour, and social conditions. ${ }^{100}$ Positive psychology is the scientific study of a healthy and flourishing life. Positive psychology (sattva lakshana samyogo) is concerned with positive psychological states (eg, happiness), positive psychological traits (eg, talents, interests, strengths of character) (purusha shubha lakshana), positive relationships, and positive institutions (ishtaam cha aparaan bhaavaan). Evidence is accumulating that a happy, engaged, and fulfilling psychological and social life leads people to live a healthy and long life. ${ }^{101}$ The new science of psychoneuroimmunology (PNI) has more than validated age-old human wisdom about the unity of mind and body, showing that the emotion-processing centres of the brain are inextricably linked with the nervous system, the immune system, and the hormonal apparatus. PNI studies the interactions between the sciences of immunology, endocrinology, and psychology/ neuroscience. ${ }^{102}$ The above verse is realted to the various concepts like 'Health psychology', 'Positive psychology' and PNI.

\section{Psychiatric conditions in Charaka indriya sthana}

\section{Hallucinations}

Hallucinations are perceptions in the absence of an external stimulus and are accompanied by a compelling sense of their reality. ${ }^{103}$ The term "organic" applied to psychosis is meant to convey the emergence of hallucinations or delusions in a patient with a recently acquired disturbance of brain function. Organic or secondary psychosis can be seen in diverse conditions such as toxic or metabolic disorders, neurodegenerative disease, and stroke. ${ }^{104}$ Various references found in 'Charaka indriya sthana' denotes hallucinations of organic or secondary origin (having some underlying brain pathology).

\section{'Swasthebhyo --- maranasya tat' (Verse 5$)^{6}$}

In the fouth chapter of 'Charaka indriya sthana' (indriyaneekam indriyam), 'Acharya Charaka' states that, 'the perception pertaining to the sensory organs which is abnormal and arisen without any apparent cause indicates imminent death'. ${ }^{105}$ The above verse denotes hallucination (vikrutam yasya gnaanam) due to secondary or organic origin without having pathology (animittena) at the level of sensory 
organs. The above verse also denotes perceptual distortions or agnosia or and other sensory impairments due to an underlying brain pathology.

\section{'Ghaneebhutamiva --- marana mruchhati' (Verse 7) ${ }^{6}$}

As per the above verse, 'the patient who sees the sky as solidified like earth or sees the earth like the sky, or both in contradiction attains death' ${ }^{105}$ The above verse denotes visual hallucinations ${ }^{105}$ or visual perceptual distortions. ${ }^{6}$

\section{'Yasya darshanam --- kshayam aadishet' (Verse 8) ${ }^{6}$}

According to the above verse, 'one who sees air moving in the sky but does not visualize the burning fire should be taken for lost'. This verse also denotes visual hallucinations. ${ }^{105}$

\section{'Jagruta --- jeevitu marhati' (Verse 10) ${ }^{6}$}

The above verse indicates that, "while awake, if one visualizes ghosts and various demons or some other bizarre things, he/she is unable to live'. This verse also denotes visual hallucinations. ${ }^{105}$

\section{'Mareechi --- marana mruchhati' (Verse 12) 6}

Above verse demonstrates that, "If one sees rays of light without clouds, if one sees clouds in the sky though not there or if one sees lightning when there are no clouds, he/she attains death'. This verse denotes visual hallucinations. ${ }^{105}$

\section{'Aparvani --- tasya jeevitam' (Verse 14) ${ }^{6}$}

As per the above verse, 'If a diseased person or healthy person visualizes solar eclipse or lunar eclipse though it is not there, it indicates death'. The above verse denotes either 'Visual hallucinations' ${ }^{105}$ or 'Achromatopsia' or 'Scierneuropsia' or 'Hemeralopia'. ${ }^{6}$

\section{'Naktam suryam --- mruchhati' (Verse 15)}

According to the above verse, 'If one sees the sun during the night and moon during daytime, smoke rising without fire or lusterless fire in the night, he/she is going to die'. The above verse denotes either visual hallucinations ${ }^{105}$ or Achromatopsia. ${ }^{6}$

\section{'Yashcha pashyati adrushyaan' (Verse 18) ${ }^{6}$}

The above vese demonstrates that, 'if a person sees nonvisible objects or does not see the visible ones, he/she dies soon'. This verse also denotes visual hallucinations ${ }^{105}$ or 'Visual anosognosia' .

\section{'Ashabdasya cha --- vijaanataa'(Verse 19) ${ }^{6}$}

According to the above verse, 'one who hears sounds when there is none or does not perceive the real sound should be considered to be dead'. This verse indicates 'Auditory hallucniations' ${ }^{105}$ or 'Auditory agnosia'. ${ }^{6}$

\section{'Viparyayena --- vigataayusham'(Verse 21) ${ }^{6}$}

According to the above verse, 'if one perceives good smell and bad smell in contrary, or does not perceive the smell entirely should be considered to have completed his/her life span'. This verse indicates 'Olfactory hallucniations' ${ }^{105}$ or 'Anosmia' or 'Parosmia' or 'Cacosmia' or 'Dysosmia'.

\section{'Yo rasaanna --- kushala naram'(Verse 22) ${ }^{6}$}

According to the above verse, "if one does not perceive the taste even in the absence of any kind of inflammation in the mouth or perceives altered taste, he/she should be considered to die soon'.
This verse indicates 'Gustatory hallucniations' ${ }^{105}$ or 'Ageusia' or 'Pargeusia' or 'Dysgeusia' or 'Hypogeusia'. ${ }^{6}$

\section{'Ushnaan cha --- steshu manyate'(Verse 23) ${ }^{6}$}

As per the above verse, 'if one perceives touch sensations such as hot-cold, coarse-smooth, and soft-hard in an opposite way (contrarily), he/she is about to die'. This verse indicates 'Tactile hallucniations' 105 or 'Allodynia' or 'Paresthesia' or 'Dysesthesia' or 'Lack of tactile discrimination ability' ${ }^{6}$

\section{'Indriyai adhikam pashyan'(Verse 24)}

As per the above verse, 'super sensory perceptions without any rigorous penance (tapas) or methodical yoga, indicate death' ${ }^{105}$ The above verse indicates 'Visual hallucinations' or 'ESP'. ${ }^{6}$

\section{'Indriyaanaamrute --- na sa jeevati' (Verse 25) ${ }^{6}$}

The above verse demonstrates that, 'if one perceives all senses correctly in spite of incapability of sense organs, it indicates death' ${ }^{105}$ Charles Bonnet syndrome (CBS) is characterized by visual hallucinations (naro pashyati ya) in patients without mental illness (indriyaarthan adoshajaan). Patients with CBS have shown history of diminished visual acuity or visual field loss (indriyaanaamrute). Patients of CBS do not have any significant metabolic derangements or impaired sensorium that would otherwise explain their symptoms. The currently accepted theory suggests that vision loss (ndriyaanaamrute) leads to visual sensory de-afferentation, causing disinhibition, and later spontaneous firing, of the visual cortical regions in CBS patients. ${ }^{106}$ The above verse denotes various conditions like, 'Mental imagery', 'Phantom perception', 'Neuroplasticity', 'Synesthesia', CBS and 'Hallucinations' etc.

\section{'Swasthaa --- marana maadishet' (Verse 26) ${ }^{6}$}

The above verse demonstrates that, "if a healthy person contrary to his intellect repeatedly perceives abnormal sensations though there is no object of stimulus, it indicates death'. ${ }^{105}$ Diseases of the brain are frequently manifested by psychiatric symptomatology, a condition conventionally termed 'Organic Brain Syndrome' (OBS). Symptoms suggestive of cognitive impairment (pragnaaviparyaya) in OBS may even persist in a proportion of cases long after the initial episode, especially when the cerebral insult is irreversible (marana maadishet).$^{107} \mathrm{NCDs}$ are referred as 'organic', implying that they manifest due to known structural brain disease. $\mathrm{AD}$, cerebrovascular disease, FTLD, DLB, HD, TBI, HIV disease, prion disease and substance-use-associated disease etc comes under the category of NCDs. The term "neurocognitive" describes cognitive functions are closely linked to the function of particular brain regions, neural pathways, or cortical/subcortical networks in the brain. ${ }^{108}$ The above verse denotes cognitive distoritions seen in OBS or NCDs.

\section{'Laksha rakta --- antaaya neeyate'(Verse 10) ${ }^{7}$}

As per the above verse, 'one who sees his/her clothers as dyed with red 'Lac', he/she will die by getting afflicted with bleeding disorder'. Seeing everything as red colored denotes visual hallucinations or vascular neuro-ophthalmological condition or vascular dementia or hypertensive encephalopathy. ${ }^{6}$

\section{'Apaswaram --- parivarjayet' (Verse 14) ${ }^{11}$}

The above verse denotes abnormal vocalizations or speech and auditory hallucinations seen in various conditions such as PD, dementias, and delirium. Auditory hallucinations (shrotaaram ashabdasya) can be seen in $\mathrm{AD}$ and DLB patients. ${ }^{57}$ 


\section{'Ayogam atiyogam --- naavachaarayet' (Verse 22) ${ }^{13}$}

The above verse denotes 'Sensory impairments', 'Agnosia', and 'Hallucinations' seen in dementia and delirium. Agnosia (ayogam), communication and language impairments and hallucinations (atiyogam) can be seen in various sub types of dementia such as $\mathrm{AD}$, DLB, FTD and VaD. ${ }^{17}$ All the above references discussed under the section of 'Hallucinations' denotes OBS or NCDs.

\section{Catatonia \& Schizophrenia}

\section{'Ahara dveshinam --- ati paatinaa'(Verse 19)'}

Catatonia of the retarded type is associated with signs reflecting a paucity of movement, including immobility, staring, mutism (lupta chittam), rigidity, withdrawal and refusal to eat (aahaara dveshinam), posturing, grimacing, negativism, waxy flexibility, echolalia or echopraxia, stereotypy, verbigeration, and automatic obedience. ${ }^{109}$ Blunted affect (diminished facial and emotional expression) (lupta chittam), alogia (decrease in verbal output or verbal expressiveness) (lupta chittam), asociality (lack of involvement in social relationships of various kinds), avolition (a subjective reduction in interests, desires, and goals and a behavioral reduction of self-initiated and purposeful acts), and anhedonia (inability to experience pleasure from positive stimuli) are considered as negative symptoms of schizophrenia (lupta chittam). ${ }^{110}$ Major depressive disorder (MDD) (lupta chittam) is a leading cause of chronic disability and mortality (mumurshu). Decreased appetite (aahaara dveshinam) is the fature of MDD. ${ }^{111}$ The above verse denotes catatonia or negative symptoms of schizophrenia or MDD.

\section{'Yairvindati --- maranamaadishet' (Verse 21) ${ }^{10}$}

The above verse denotes 'Anhedonia'. Depressed mood and anhedonia are the cardinal features of MDD. Anhedonia is defined as a 'markedly diminished interest or pleasure in all, or almost all, activities of the day' (taireva aramamaanasya glaasno) suggesting pleasure experiences in anhedonia are flat and blunted. ${ }^{112}$ The term 'Cotard's syndrome' (CS) is used to describe a number of clinical features, mostly hypochondriac and nihilistic delusions (taireva aramamaanasya glaasno). Besides, anxious and depressed mood (taireva aramamaanasya glaasno), delusions of damnation, possession and immortality, suicidal and self-mutilating behavior (maranamaadishet) are also the features of CS. ${ }^{113}$ The above verse indicates conditions like MDD or CS or Mood disorder.

\section{Bruxism \& Trichotillomania}

\section{'Dantaichhindan --- parimuchyate' (Verse 18) ${ }^{10}$}

The above verse denotes 'Nail biting', 'Trichotillomania' and 'Mannerisms or stereotypies'. Trichotillomania (TTM), or hairpulling disorder (nakhaichhindaan shiroruhaan), is characterized by the repeated removal (or pulling) of hair from the body, resulting in significant hair loss. Most commonly, the hands, particularly the thumb and forefinger, (nakhaichhindaan) are used to remove the hair. The most common site from which pulling occurs is the scalp (shiroruhaan). Along with TTM disruption of control mechanisms have also been found with varying degrees of motor dysfunction in conditions like 'Tourette's syndrome' (TS) and 'Obsessive compulsive disorder' (OCD). BFRBs (body focused repetitive behaviours) such as skin picking, nail biting (dantaichhindan nakhaagraani), and cheek biting etc are frequently comorbid with TTM. TTM is comorbid with various other conditions like, OCD, anxiety disorders, mood disorders, tic disorder and attention-deficit/hyperactivity disorder (ADHD). ${ }^{114}$ TTM can also be seen in FTD. Various self injurious behaviors
(SIB) are seen in children with autism and mental retardation. Major stereotypies (kaashtena bhumim vilikhan) shown by children with pervasive developmental disorders (PDD) are repetitive, compulsive, stereotypical, and rhythmic behaviors such as self-biting, face/head banging or hitting, handshaking, body rocking, mouthing of objects, picking at skin or body orifices, hair pulling (nakhaichhindaan shiroruhaan), breath holding, and swallowing (aerophagia). ${ }^{115}$ The literature indicates that simple motor stereotypy such as skin-picking, head rocking, and lip pursing and complex motor stereotypy like hair-pulling, skin-picking, hand flapping, and wriggling with leg movement (kaashtena bhumim vilikhan) involve frontostriatal disease or dysfunction. ${ }^{116}$ The above verse denotes stereotypic movement disorder or TTM or BFRBs due to various underlying neurological syndromes.

\section{'Dantaan khaadati --- vimuchyate' (Verse 19) ${ }^{10}$}

FTD is a neurodegenerative disorder occurs due to frontal and temporal lobar atrophy and it is characterized by troubling \& progressive changes in behavior, personality, judgment, language, and cognition. Decreased response to pain (dukham na vijaanaati) is seen in 'Apathetic subtype of FTD'. FTD patients have shown significant impairment in emotion recognition for the fear and sad film clips (virudhan hasan). Magnetic resonance imaging (MRI) volumetrics revealed that deficits in emotion recognition were associated with decreased frontal and temporal lobar volumes seen in FTD patients. ${ }^{117}$ Awake bruxism is defined as an oral parafunctional activity that includes clenching and grinding of teeth during wakefulness (dantaan khaadati yo jaagruta). Awake bruxism (dantaan khaadati yo jaagruta) is seen in the patients of FTD, AD, PD and Stroke. ${ }^{118}$ The above verse denotes a condition of 'Awake bruxism in FTD' patients.

\section{'Pramuhya --- kaalachodita'(Verse 17) ${ }^{13}$}

The above verse denotes TTM or Agitation. Patient with FTD may present with TTM (lunchayet keshaan), agitation (lunchayet keshaan), anger, disinhibitory behavior, food faddism (nara swasthavat aahaaram) and apathy (abala?). The main neuropsychiatric manifestations of FTD include disinhibition, apathy, obsessive-compulsive behavior, and Kluver-Bucy syndrome (KBS). ${ }^{115}$ Hyperoralitly (nara swasthavat aahaaram), increased preference for sweet foods (nara swasthavat aahaaram) and poor insight (pramuhya) are found in FTD patients. ${ }^{117}$ Despite having hyperorality and food faddisms (nara swasthavat aahaaram) etc, FTD patients show features like apathy (abala). The above verse indicates TTM in FTD patients.

\section{Nightmares}

\section{'Drushyante --- pretaakrutirudeeryate' (Verse 59) $)^{14}$}

Nightmares (drushyante daaruna swapna) are common in intensive care unit (ICU) patients. Nightmares may have been interpreted by patients as an extremely unpleasant (dauraatmyamupajaayate) dream. ${ }^{119}$ Critically ill patients reported a high incidence of recall for unpleasant events (dauraatmyamupajaayate), and the patients who stayed longer than 24 hours at the ICU, indicated vivid memory for nightmares and hallucinations. ${ }^{120}$ Post-traumatic stress disorder (PTSD) and resultant nightmares are well-recognized complications (dauraatmyamupajaayate) of severe illness that have been described in ICU patients after multiple trauma, burns, myocardial infarction, acute respiratory distress syndrome or septic shock. ${ }^{121}$ Sleep disturbances in critically ill patients are associated with poorer longterm clinical outcomes (pretaakrutirudeeryate) and quality of life. ${ }^{122}$ The above verse denotes nightmares commonly seen in ICU patients and indicate poor prognosis. 


\section{Conclusion}

Charaka Samhita is the ancient and most authentic treatise on Ayurveda. Indriya sthana of Charaka samhita deals with prognostic aspects. Various psychiatric and neuropsychiatric disorders are mentioned throughout 'Charaka indriya sthana' in a scattered form. 'Dementia' and 'Delirium' are the two most common conditions found through out 'Charaka indriya sthana'. Various references related to other psychiatric and neuropsychiatric conditions like, 'Hallucinations', 'Trichotillomania', 'Awake bruxism', 'Impulse control disorders', 'Major depressive disorder', 'Catatonia'. 'Negative symptoms of Schizophrenia' are also mentioned in 'Charaka indriya sthana'. Most of the psychiatric conditions of 'Charaka indriya sthana' are 'organic' or 'secondary' in nature and they are characterized by having poor prognosis and commonly found in dying patients or at the end-of-life stages. The contemporary perspective of ancient psychiatric concepts mentioned in 'Charaka indriya sthana' as demonstrated in the present article provides new insights and paves way further studies and also the psychiatric conditions mentioned in it have clinical applicability and prognostic significance in present era also.

\section{Acknowledgments}

None.

\section{Conflicts of interest}

Authors declare that there is no conflict of interest.

\section{References}

1. Bhavana KR, Shreevathsa. Medical geography in Charaka Samhita. Ayu. 2014;35(4):371-377.

2. Nipane MS, Chouagade B, Chouragade N, et al. Relevance of indriya sthan in the prognosis of diseases: A review. Int J Res Ayurveda Pharm. 2018;9(1):9-12.

3. Mamidi P, Gupta K. Varna swareeyam of Charaka Indriya sthana - An explorative study. Int J Ayu Alt Med. 2019;7(5):152-175.

4. Gupta K, Mamidi P. Pushpitakam of Charaka Indriya sthana - An explorative study. Int J Ayu Alt Med. 2019;7(5):176-182.

5. Mamidi P, Gupta K. Parimarshaneeyam of Charaka Indriya sthana - An explorative study. Int J Ayu Alt Med. 2019;7(5):183-191.

6. Gupta K, Mamidi P. Indriyaaneekam of Charaka Indriya sthana - An explorative study. Int J Ayu Alt Med. 2019;7(5):192-202.

7. Mamidi P, Gupta K. Purvarupeeyam of Charaka Indriya sthana - An explorative study. Int J Ayu Alt Med. 2019;7(5):203-212.

8. Gupta K, Mamidi P. Katamani shaririyam of Charaka Indriya sthana An explorative study. Int J Ayu Alt Med. 2019;7(5):213-222.

9. Mamidi P, Gupta K. Panna rupeeyam of Charaka Indriya sthana - An explorative study. Int J Ayu Alt Med. 2019;7(6):223-235.

10. Gupta K, Mamidi P. Avaak shirasiyam of Charaka Indriya sthana - An explorative study. Int J Ayu Alt Med. 2019;7(6):236-251.

11. Mamidi P, Gupta K. Yasya shyaava nimitteeyam of Charaka Indriya sthana - An explorative study. Int J Ayu Alt Med. 2019;7 (6):252-263.

12. Gupta K, Mamidi P. Sadyo maraneeyam of Charaka Indriya sthana - An explorative study. Int J Ayu Alt Med. 2019;7(6):264-273.

13. Mamidi P, Gupta K. Anu jyoteeyam of Charaka Indriya sthana - An explorative study. Int J Ayu Alt Med. 2019;7(6):274-287.

14. Gupta K, Mamidi P. Gomaya choorneeyam of Charaka Indriya sthana An explorative study. Int J Ayu Alt Med. 2019;7(6):288-306.
15. Shaji KS, Sivakumar PT, Rao GP, et al. Clinical Practice Guidelines for Management of Dementia. Indian J Psychiatry. 2018;60(Suppl 3):S312-S328.

16. Hapca S, Guthrie B, Cvoro V, et al. Mortality in people with dementia, delirium, and unspecified cognitive impairment in the general hospital: prospective cohort study of 6,724 patients with 2 years follow-up. Clin Epidemiol. 2018;10:1743-1753.

17. Duong S, Patel T, Chang F. Dementia: What pharmacists need to know. Can Pharm J (Ott). 2017;150(2):118-129.

18. Cunningham EL, McGuinness B, Herron B, et al. Dementia. Ulster Med J. 2015;84(2):79-87.

19. Grover S, Avasthi A. Clinical Practice Guidelines for Management of Delirium in Elderly. Indian J Psychiatry. 2018;60(Suppl 3):S329-S340.

20. Fong TG, Tulebaev SR, Inouye SK. Delirium in elderly adults: diagnosis, prevention and treatment. Nat Rev Neurol. 2009;5(4):210-220.

21. Martins S, Fernandes L. Delirium in elderly people: a review. Front Neurol. 2012;3:101.

22. Cerejeira J, Lagarto L, Mukaetova-Ladinska EB. Behavioral and psychological symptoms of dementia. Front Neurol. 2012;3:73.

23. Wongrakpanich S, Petchlorlian A, Rosenzweig A. Sensorineural Organs Dysfunction and Cognitive Decline: A Review Article. Aging Dis. 2016;7(6):763-769.

24. Hirakawa Y, Uemura K. Signs and Symptoms of Impending Death in Endof-life Elderly Dementia Sufferers: Point of View of Formal Caregivers in Rural Areas: A Qualitative Study. J Rural Med. 2012;7(2):59-64.

25. Park KH, Park KJ. Neurological aspects of anhidrosis: differential diagnoses and diagnostic tools. Ann Clin Neurophysiol. 2019;21(1):1-6.

26. Teeple RC, Caplan JP, Stern TA. Visual hallucinations: differential diagnosis and treatment. Prim Care Companion J Clin Psychiatry. 2009;11(1):26-32.

27. Chaudhury S. Hallucinations: Clinical aspects and management. Ind Psychiatry J. 2010;19(1):5-12.

28. Colligris P, Perez de Lara MJ, Colligris B, et al. Ocular Manifestations of Alzheimer's and Other Neurodegenerative Diseases: The Prospect of the Eye as a Tool for the Early Diagnosis of Alzheimer's Disease. $J$ Ophthalmol. 2018;2018:8538573.

29. Uchiyama M, Nishio Y, Yokoi K, et al. Pareidolias: complex visual illusions in dementia with Lewy bodies. Brain. 2012;135(Pt 8):24582469.

30. Taylor I, Scheffer IE, Berkovic SF. Occipital epilepsies: identification of specific and newly recognized syndromes. Brain. 2003;126(4):753-769.

31. Johnson JK, Chow ML. Hearing and music in dementia. Handb Clin Neurol. 2015;129:667-687.

32. Hardy CJ, Marshall CR, Golden HL, et al. Hearing and dementia. $J$ Neurol. 2016;263(11):2339-2354.

33. Gupta K, Mamidi P. Pancha Indriya Buddhi: Association cortices. Int J Yoga - Philosop Psychol Parapsychol. 2018;6(2):61-65.

34. Waters F, Fernyhough C. Hallucinations: A systematic review of points of similarity and difference across diagnostic classes. Schizophr Bull. 2017;43(1):32-43.

35. Pasricha SK. Relevance of para-psychology in psychiatric practice. Indian J Psychiatry. 2011;53(1):4-8

36. Trojsi F, Christidi F, Migliaccio R, et al. Behavioural and Cognitive Changes in Neurodegenerative Diseases and Brain Injury. Behav Neurol. 2018;2018:4935915. 
37. Iadecola C. The pathobiology of vascular dementia. Neuron 2013;80(4):844-866.

38. Good DC. Episodic Neurologic Symptoms. In: Walker HK, Hall WD, Hurst JW, editors. Clinical Methods: The History, Physical, and Laboratory Examinations. 3rd edition. Boston: Butterworths; 1990.

39. Minaglia C, Giannotti C, Boccardi V, et al. Cachexia and advanced dementia. J Cachexia Sarcopenia Muscle. 2019;10(2):263-277.

40. Müller-Spahn F. Behavioral disturbances in dementia. Dialogues Clin Neurosci. 2003;5(1):49-59.

41. Keeley PW. Delirium at the end of life. BMJ Clin Evid. 2009;2009:2405.

42. Hui D, Dev R, Bruera E. The last days of life: symptom burden and impact on nutrition and hydration in cancer patients. Curr Opin Support Palliat Care. 2015;9(4):346-354.

43. Kaplan PW. Delirium and epilepsy. Dialogues Clin Neurosci. 2003;5(2):187-200

44. Udagedara TB, Dhananjalee Alahakoon AM, Goonaratna IK. Vascular Parkinsonism: A Review on Management updates. Ann Indian Acad Neurol. 2019;22(1):17-20.

45. Williams DR, Litvan I. Parkinsonian syndromes. Continuum (Minneap Minn). 2013;19(5):1189-1212.

46. Solberg M, Koht J. Oculogyric Crises. Tremor Other Hyperkinet Mov (N Y). 2017;7:491

47. Barow E, Schneider SA, Bhatia KP, et al. Oculogyric crises: Etiology, pathophysiology and therapeutic approaches. Parkinsonism Relat Disord. 2017;36:3-9.

48. Tible OP, Riese F, Savaskan E, et al. Best practice in the management of behavioural and psychological symptoms of dementia. Ther Adv Neurol Disord. 2017;10(8):297-309.

49. Desai AK, Grossberg GT. Recognition and Management of Behavioral Disturbances in Dementia. Prim Care Companion J Clin Psychiatry. 2001;3(3):93-109.

50. Ali S, Patel M, Jabeen S, et al. Insight into delirium. Innov Clin Neurosci. 2011;8(10):25-34.

51. Varanese S, Birnbaum Z, Rossi R, et al. Treatment of advanced Parkinson's disease. Parkinsons Dis. 2011;2010:480260.

52. Harris D. Delirium in advanced disease. Postgrad Med J. 2007;83(982):525-528.

53. Irwin SA, Pirrello RD, Hirst JM, et al. Clarifying delirium management: practical, evidenced-based, expert recommendations for clinical practice. J Palliat Med. 2013;16(4):423-435

54. Lawlor PG. Delirium and dehydration: some fluid for thought? Support Care Cancer. 2002;10(6):445-454.

55. Tsunoda N, Hashimoto M, Ishikawa T, et al. Clinical Features of Auditory Hallucinations in Patients With Dementia With Lewy Bodies: A Soundtrack of Visual Hallucinations. J Clin Psychiatry. 2018;79(3):17m11623.

56. Yusupov A, Galvin JE. Vocalization in dementia: A case report and review of the literature. Case Rep Neurol. 2014;6(1):126-133.

57. El Haj M, Roche J, Jardri R, et al. Clinical and neurocognitive aspects of hallucinations in Alzheimer's disease. Neurosci Biobehav Rev. 2017;83:713-720.

58. Maclullich AM, Ferguson KJ, Miller T, et al. Unravelling the pathophysiology of delirium: a focus on the role of aberrant stress responses. J Psychosom Res. 2008;65(3):229-238.

59. Poewe W, Gauthier S, Aarsland D, et al. Diagnosis and management of Parkinson's disease dementia. Int J Clin Pract. 2008;62(10):1581-1587.
60. Meireles J, Massano J. Cognitive impairment and dementia in Parkinson's disease: clinical features, diagnosis, and management. Front Neurol. 2012;3:88.

61. Chandra SR, Patwardhan K, Pai AR. Problems of Face Recognition in Patients with Behavioral Variant Frontotemporal Dementia. Indian $J$ Psychol Med. 2017;39(5):653-658.

62. Lorenzl S, Füsgen I, Noachtar S. Acute confusional States in the elderly-diagnosis and treatment. Dtsch Arztebl Int. 2012;109(21):391-399.

63. Arcand M. End-of-life issues in advanced dementia: Part 1: goals of care, decision-making process, and family education. Can Fam Physician. 2015;61(4):330-334.

64. Girard TD, Pandharipande PP, Ely EW. Delirium in the intensive care unit. Crit Care. 2008;12(Suppl 3):S3.

65. Nolan C, DeAngelis LM. The confused oncologic patient: a rational clinical approach. Curr Opin Neurol. 2016;29(6):789-796.

66. Chwistek M. Recent advances in understanding and managing cancer pain. F1000Res. 2017;6:945

67. Schneider G, Voltz R, Gaertner J. Cancer Pain Management and Bone Metastases: An Update for the Clinician. Breast Care (Basel) 2012;7(2):113-120.

68. Borda LJ, Wikramanayake TC. Seborrheic Dermatitis and Dandruff: A Comprehensive Review. J Clin Investig Dermatol. 2015;3(2):10.13188/2373-1044.1000019.

69. Laurence M, Benito-León J, Calon F. Malassezia and Parkinson's disease. Front Neurol. 2019;10:758.

70. Fong TG, Davis D, Growdon ME, et al. The interface between delirium and dementia in elderly adults. Lancet Neurol. 2015;14(8):823-832.

71. Yiannopoulou KG, Papageorgiou SG. Current and future treatments for Alzheimer's disease. Ther Adv Neurol Disord. 2013;6(1):19-33.

72. Tonelli M, Wiebe N, Straus S, et al. Multimorbidity, dementia and health care in older people:a population-based cohort study. CMAJ Open 2017;5(3):E623-E631.

73. Martorana A, Bulati M, Buffa S, et al. Immunosenescence, inflammation and Alzheimer's disease. Longev Healthspan. 2012;1:8

74. Lawlor PG, Bush SH. Delirium diagnosis, screening and management. Curr Opin Support Palliat Care. 2014;8(3):286-295.

75. Brenowitz WD, Kaup AR, Lin FR, et al. Multiple Sensory Impairment Is Associated With Increased Risk of Dementia Among Black and White Older Adults. J Gerontol A Biol Sci Med Sci. 2019;74(6):890-896.

76. Wilson RS, Gilley DW, Bennett DA, et al. Hallucinations, delusions, and cognitive decline in Alzheimer's disease. J Neurol Neurosurg Psychiatry. 2000;69(2):172-177.

77. Prasad Mamidi, Kshama Gupta. Obsessive compulsive disorder'Sangama graha': An Ayurvedic view. J Pharm Sci Innov. 2015;4(3):156164.

78. Mamidi P, Gupta K. Pittaja Unmada: Hyperthyroidism with mania? / Psychotic or irritable mania? Int J Yoga-Philosop Psychol Parapsychol. 2020;8(2):47-57.

79. Gupta K, Mamidi P. Vataja Unmada: Schizophrenia or dementia or mood disorder with psychosis? Int J Yoga - Philosop Psychol Parapsychol. 2020;8(2):75-86.

80. Gupta K, Mamidi P. Kaphaja unmada: Myxedema psychosis? Int J Yoga - Philosop Psychol Parapsychol. 2015;3(2):31-39.

81. Mamidi P, Gupta K. Guru, vriddha, rishi and siddha grahonmaada: Geschwind syndrome? Int $J$ Yoga-Philosop Psychol Parapsychol. $2015 ; 3(2): 40-45$. 
82. Gupta K, Mamidi P. Gandharva grahonmada: Bipolar disorder with obsessive-compulsive disorder/mania? Int J Yoga - Philosop Psycho Parapsychol. 2017;5(1):6-13.

83. Mamidi P, Gupta K. Vetaala Grahonmada: Parkinson's disease with obsessive-compulsive disorder?/Autoimmune neuropsychiatric disorder? Int J Yoga - Philosop Psychol Parapsychol. 2017;5(2):35-41.

84. Gupta K, Mamidi P. Deva shatru/Daitya/Asura grahonmada: Antisocial/ Narcissistic/Borderline personality disorder? Int J Yoga - Philosop Psychol Parapsychol. 2018;6(1):10-15.

85. Gupta K, Mamidi P. Yaksha grahonmada: Bipolar disorder with obsessive-compulsive disorder? Int J Yoga - Philosop Psychol Parapsychol. 2018;6(1):16-23.

86. Gupta K, Mamidi P. Deva grahonmada: Interictal behavior syndrome of temporal lobe epilepsy? / Obsessive-compulsive disorder with mania? Int J Yoga - Philosop Psychol Parapsychol. 2018;6(1):41-50.

87. Mamidi P, Gupta K. Rakshasa grahonmada: Antisocial personality disorder with psychotic mania? Int J Yoga - Philosop Psychol Parapsychol. 2018;6(1):24-31.

88. Mamidi P, Gupta K. Brahma rakshasa grahonmada: Borderline personality disorder? / tourette syndrome - plus? Int J Yoga - Philosop Psychol Parapsychol. 2018;6(1):32-40.

89. Gupta K, Mamidi P. Nishaada grahonmada: Behavioral and Pscyhological symptoms of dementia? / Frontotemporal dementia? Hebephrenia? J Neuro Behav Sci. 2018;5(2):97-101.

90. Mamidi P, Gupta K. Uraga grahonmada: Extrapyramidal movement disorder?/Tourette syndrome-Plus? Indian J Health Sci Biomed Res. 2018;11(3):215-221.

91. Gupta K, Mamidi P. Preta grahonmada - Catatonia? Med J DY Patil Vidyapeeth. 2018;11(6):461-465.

92. Mamidi P, Gupta K. Maukirana grahonmada - Psychiatric manifestations of Graves' hyperthyroidism and ophthalmopathy?. Med J DY Patil Vidyapeeth. 2018;11(6):466-470.

93. Gupta K, Mamidi P. Kushmanda grahonmada - Paraneoplastic neurological syndrome with testicular cancer? J Neuro Behav Sci. 2018;5(3):172-176.

94. Gupta K, Mamidi P. Bhutonmada's of Harita samhita-An explorative study. Int J Yoga-Philosop Psychol Parapsychol. 2020;8(1):3-12.

95. Kandler C, Bleidorn W. The Genetic and Environmental Contributions to Personality Differences and Development. In Wright JD (ed). The international encyclopaedia of social and behavioural sciences (2nd ed). 884-890 p.

96. Saposnik G, Redelmeier D, Ruff CC, et al. Cognitive biases associated with medical decisions: a systematic review. BMC Med Inform Decis Mak. 2016;16(1):138.

97. Esteban-Zubero E, Valdivia-Grandez MA, Alatorre-Jiménez MA, et al. Diagnosis Bias and its Revelance During the Diagnosis Process. Arch Clin Med Case Rep. 2017;1(1):24-30.

98. O'Sullivan ED, Schofield SJ. Cognitive bias in clinical medicine. $J R$ Coll Physicians Edinb. 2018;48(3):225-232.

99. Snellman I, Gustafsson C, Gustafsson LK. Patients' and caregivers' attributes in a meaningful care encounter: similarities and notable differences. ISRN Nurs. 2012;2012:320145.

100. Kaplan RM. Health psychology: where are we and where do we go from here? Mens Sana Monogr. 2009;7(1):3-9.

101. Park N, Peterson C, Szvarca D, et al. Positive Psychology and Physical Health: Research and Applications. Am J Lifestyle Med. 2014;10(3):200206.
102. Maté G. The science of psychoneuroimmunology. Can Fam Physician. 2005;51(4):489.

103. Boksa P. On the neurobiology of hallucinations. J Psychiatry Neurosci. 2009;34(4):260-262.

104. Joyce EM. Organic psychosis: The pathobiology and treatment of delusions. CNS Neurosci Ther. 2018;24(7):598-603.

105. Balsavar A, Deshpande SN. Hallucinations in the classical Indian system of Ayurveda: A brief overview. Indian J Psychiatry. 2014;56(4):325329.

106. Jan T, Del Castillo J. Visual hallucinations: charles bonnet syndrome. West J Emerg Med. 2012;13(6):544-547.

107. Chandrasekaran PK, Jambunathan ST, Zainal NZ. Characteristics of patients with organic brain syndromes: A cross-sectional 2-year followup study in Kuala Lumpur, Malaysia. Ann Gen Psychiatry. 2005;4(1):9.

108. Ganguli M, Blacker D, Blazer DG, et al. Classification of neurocognitive disorders in DSM-5: a work in progress. Am J Geriatr Psychiatry. 2011;19(3):205-210.

109. Rasmussen SA, Mazurek MF, Rosebush PI. Catatonia: Our current understanding of its diagnosis, treatment and pathophysiology. World $J$ Psychiatry. 2016;6(4):391-398.

110. Mitra S, Mahintamani T, Kavoor AR, et al. Negative symptoms in schizophrenia. Ind Psychiatry J. 2016;25(2):135-144.

111. Simmons WK, Burrows K, Avery JA, et al. Depression-Related Increases and Decreases in Appetite: Dissociable Patterns of Aberrant Activity in Reward and Interoceptive Neurocircuitry. Am J Psychiatry. 2016;173(4):418-428.

112. Heininga VE, Dejonckheere E, Houben M, et al. The dynamical signature of anhedonia in major depressive disorder: positive emotion dynamics, reactivity, and recovery. BMC Psychiatry. 2019;19(1):59.

113. Moschopoulos NP, Kaprinis S, Nimatoudis J. Cotard's syndrome: Case report and a brief review of literature. Psychiatriki. 2016;27(4):296-302.

114. Woods DW, Houghton DC. Diagnosis, evaluation, and management of trichotillomania. Psychiatr Clin North Am. 2014;37(3):301-317.

115. Issac TG, Telang AV, Chandra SR. Trichotillomania Ranging from "Ritual to Illness" and as a Rare Clinical Manifestation of Frontotemporal Dementia: Review of Literature and Case Report. Int J Trichology. 2018;10(2):84-88.

116. Paholpak P, Mendez MF. Trichotillomania as a Manifestation of Dementia. Case Rep Psychiatry. 2016;2016:9782702.

117. Wittenberg D, Possin KL, Rascovsky K, et al. The early neuropsychological and behavioral characteristics of frontotemporal dementia. Neuropsychol Rev. 2008;18(1):91-102.

118. Kwak YT, Han IW, Lee PH, et al. Associated conditions and clinical significance of awake bruxism. Geriatr Gerontol Int. 2009;9(4):382390

119. Guttormson JL. Releasing a lot of poisons from my mind": patients' delusional memories of intensive care. Heart Lung. 2014;43(5):427431

120. Rundshagen I, Schnabel K, Wegner C, et al. Incidence of recall, nightmares, and hallucinations during analgosedation in intensive care. Intensive Care Med. 2002;28(1):38-43.

121. Matthews EE. Sleep disturbances and fatigue in critically ill patients. AACN Adv Crit Care. 2011;22(3):204-224.

122. Wang S, Meeker JW, Perkins AJ, et al. Psychiatric symptoms and their association with sleep disturbances in intensive care unit survivors. Int $J$ Gen Med. 2019;12:125-130. 